\title{
A simple and inexpensive method for producing and maintaining closed pot cultures of arbuscular mycorrhizal fungi
}

\author{
Christopher Walker and Mauritz Vestberg \\ Walker, C. ' \& Vestberg, M. ${ }^{2}$ 1994. A simple and inexpensive method for \\ producing and maintaining pot cultures of arbuscular mycorrhizal fungi. Agri- \\ cultural Science in Finland 3: 233-240. (' Forestry Commission, The Forestry \\ Authority, Northern Research Station, Roslin, Midlothian, Edinburgh EH25 9SY, \\ United Kingdom and, ${ }^{2}$ Laukaa Research and Elite Plant Unit, FIN-41340 Laukaa, \\ Finland.) \\ Trials and experiments were carried out to develop and test a simple and inexpen- \\ sive method for producing and maintaining pot cultures of arbuscular mycorrhizal \\ fungi. A commercially available, transparent bag, incorporating a micro-filter to \\ allow gaseous exchange, was successfully tested, and found to satisfy the basic \\ requirements of low cost, ready availability, ease of use, and adaptability. Pot \\ cultures were produced and maintained in various substrates with several different \\ plants. The system can be used for producing trap cultures, or for initiating and \\ maintaining pure (multi- and single-spore) ramets of mycorrhizal members of the \\ Glomales in growth chambers and greenhouses. As well as providing a means for \\ maintaining fungal ramet purity, the system has the advantage of requiring less \\ watering and maintenance than open pot cultures.
}

Key words: Glomales, Sunbags®, Glomus, Acaulospora, Gigaspora

\section{Introduction}

Arbuscular mycorrhizal fungi, members of the Glomales, have not yet been cultured axenically on completely defined media, and normally their isolation and maintenance is accomplished by means of open pot-cultures (GILMORE 1968). Methods have been developed to increase success of isolation, e.g., in Petri dishes or on agar slopes (Mosse 1962), or other containers (ALLEN et al. 1979, Allen and St. John 1982, MacDonALD 1981, Melhuish et al. 1990), but these must still be transferred to open pot culture if they are to be maintained for long periods. Open pot cultures are prone to contamination with other mycorrhizal fungi, and are expensive to maintain. To overcome the problem of contamination, systems have been developed which include root organ culture (MOSSE and HEPPER 1975) and culture in jars containing sterilised substrate (BOUDARGA and DEXHEIMER 1990). The expense of maintaining open pot cultures in a greenhouse can be reduced by automated watering systems (e.g., MILNER and KITT 1992) but this does not eliminate the danger of contamination.

Pot cultures can become contaminated with other arbuscular mycorrhizal fungi in several ways. For example, pots may be placed too close together, or not raised above a bench surface, resulting in contamination by water splash or by hyphal growth between pots. Animals, such as arthropods or rodents can also transfer propagules 
from one pot to another. The only way to prevent such contamination is to maintain cultures in a completely isolated environment. It seemed possible that such an environment could be obtained at relatively low cost and with minimal effort by using commercially-available tissue culture apparatus. This might also reduce the work of watering and maintenance (e.g., insect pest control) of open pots, and would allow different cultures to be placed in juxtaposition, making more efficient use of space. Most tissue culture chambers were found to be either prohibitively expensive, or too small. However, the Sunbag from the Sigma Chemical Company Ltd., appeared to be suitable, and was consequently tested. This bag consists of a transparent autoclavable material, in which a micro-pore panel $(0.02 \mu \mathrm{m}$ pore size $)$ is incorporated to allow exchange of gases (including water vapour). The panel's small size restricts (though does not eliminate) water loss, resulting in high humidity within the bags.

\section{Material and methods}

Sunbags (Sigma catalogue number B7026) were used for all trials and experiments. Existing open pot cultures were taken from the germ-plasm collection held at the Forestry Authority's Northern Research Station, Roslin, Scotland, or at the Laukaa Research and Elite Plant Unit, Laukaa, Finland. The principal plants used were Plantago lanceolata L. and Fragaria $x$ ananassa Duch., though other plants such as $P$. major L., $F$. vesca L., Festuca ovina L. and Plectranthus australis were also tried. $P$. lanceolata grows particularly well at low light levels, and is suitable for use in relatively low-technology growth cabinets such as might be constructed locally with banks of fluorescent lights. It also grows well in greenhouses during winter with minimal supplemental lighting. At Edinburgh, the sand mixture used was prepared by mixing commercially available local quartz sands to give a particle size structure of $>425 \mu \mathrm{m}, 69 \%$; 250-425 $\mu \mathrm{m}, 15 \%$; 180$250 \mu \mathrm{m}, 8 \%$; $<180 \mu \mathrm{m}, 8 \%$. The $\mathrm{pH}$ of the sand mixture (water) was 6.8 , and conductivity was $35 \mu \mathrm{S} \mathrm{cm}^{-1}$. For the experimental work at Edinburgh, a commercial soil-based substrate (Calval) similar to John Innes No. 1 was also purchased from a local garden centre. Tapwater or distilled water was used for watering, depending on the level of sterility required.

At Laukaa, micropropagated strawberry, Fragaria $x$ ananassa Duch. 'Senga Sengana', were grown in a peat-sand-vermiculite mix $(8: 1: 1)$ limed with $3 \mathrm{~g} \mathrm{l}^{-1}$ Dolomite lime (Saxo Oy, Finland) to give an approximate $\mathrm{pH}$ of 5.0 and fertilised with $0.5 \mathrm{~g} \mathrm{l}^{-1}$ Osmocote Plus $(16 \mathrm{~N}-3 \mathrm{P}-11 \mathrm{~K}$, 8-9 month longevity). The peat was a light Sphagnum peat (VAPO Oy, Finland) and the vermiculite (3-V, Vermipu Oy, Finland) was of large particle size. The sand was obtained from the vicinity of the research station. The peat and sand components of the substrate were steam sterilised $\left(1\right.$ hour at $100^{\circ} \mathrm{C}$ ) three times during successive days and left to allow volatile compounds to escape for at least two weeks before making up the potting mixture, care being taken to ensure that no soil or other substrate that might contain arbuscular mycorrhizal fungal propagules was handled in the vicinity to avoid any danger of contamination. For potting, Vefi (Vefi A/S, Norway) pots of 0.251 volume were used.

\section{Initial development}

Initial testing was carried out by placing existing pot cultures (standard, 9-cm diam. plastic pots) in Sunbags, and by sealing them by double-folding the top and fixing them with large plastic paper clips. These pots were weighed daily, and the evaporation estimated. Some were allowed to dry until the plants reached wilting point. From this, curves were derived to indicate when watering would be required. For example, the twicedaily watering of cultures in a sand mixture in a growth room $\left(20^{\circ} \mathrm{C}\right)$ was reduced to a single watering each week. At watering, the bags and their contents were weighed, and water was added to return them to within a few grammes of their original weight. To reduce equipment costs, an inexpensive, battery operated, electronic balance, 
available from hardware shops or department stores was used $( \pm 5 \mathrm{~g})$, and proved sufficiently accurate.

After these preliminary trials, tests were begun with seeds and seedlings. Seeds sown directly germinated and grew well, though the high humidity in the bags sometimes led to the growth of contaminating fungi resulting in damping-off. Surface sterilisation of seed solved this problem. Seedlings, germinated first on sand disinfested by autoclaving, were transplanted, after removal of the residual seedcoat, into the bags. Such seedlings grew well, requiring only intermittent watering as described above.

Inoculum from existing pot cultures was then introduced to each pot in one of two ways. In one, pot culture substrate was mixed throughout the new substrate in the pot, or placed in a layer beneath the point of sowing or seedling transplantation. The second method was by excavating a hollow in the sterilised substrate in which was placed a washed, non-mycorrhizal seedling, with roots exposed. Spores with a healthy appearance were extracted from existing pot cultures and either pipetted (multi-spore cultures), or placed as single spores, handled by use of carefully sharpened, fine-tipped forceps (Vomm Model No. 113SA, GmbH, Solingen, Germany), directly on a root. Accurate placement was assured by use of a dissecting microscope as recommended by FANG et al. (1983). The excavation was then carefully filled in, the plant watered gently with sterile distilled water from a laboratory wash-bottle, and the pots placed in the Sunbags which were then sealed as described above.

Sunbags were also used for the production of 'trap cultures'. These were produced either by mixing fresh, unsterilised soil with sand (1:1) into which a non-mycorrhizal seedling was planted, or by lifting a plant gently from soil, thoroughly washing its roots under a stream of cold tapwater, and then re-planting it in disinfested sand. Mixed cultures of arbuscular mycorrhizal fungi were established successfully with both these methods.

\section{Experiments}

Two experiments were carried out, one testing single-spore culture establishment in Scotland, and the other, in Finland, examining the establishment and sporulation of a large number of different strains of glomalean fungi. Where these fungi are registered in the Banque Européenne des Glomales (BEG), they are designated by their BEG number. Those not yet registered are referred to under their local identity numbers (FCPC for Scotland; V for Finland).

\section{Single-spore culture establishment}

Three fungi (Acaulospora longula (BEG 8), Gigaspora rosea (BEG 9), and an as yet unidentified Glomus sp. (FCPC 333) were selected that were known to grow readily under open pot-culture conditions. Two substrates were prepared; a sand mixture as previously described $(\mathrm{pH} 6.8)$, and the same mixture $(2: 1 \mathrm{v} / \mathrm{v})$ with Calval compost ( $\mathrm{pH} 6.5$ ). After mixing, these were sterilised by autoclaving at $110^{\circ} \mathrm{C}$ for $1 \mathrm{hr}$ on each of two subsequent days. Pots were filled with the appropriate substrate, and planted with a non-mycorrhizal $P$. lanceolata seedling, inoculated with a single spore placed on a root. The control pots were treated in exactly the same manner as the other treatments, except that no spore was added. Ten replicates of each treatment were prepared. They were placed in a growth room in a completely randomised design, and maintained at $27^{\circ} \mathrm{C}$ day: $15^{\circ} \mathrm{C}$ night. They were illuminated with a mixture of fluorescent and incandescent light at approximately $96 \mu \mathrm{mol} \mathrm{m}^{-2}$ $\mathrm{s}^{-1}$ until their initial sampling after 72 days. They were then transferred to a glasshouse and kept at approximately $18^{\circ} \mathrm{C}$ under normal daylight conditions for a further 7 months before the final sampling. No nutrient was added during the first 72 days, but half-strength Solinure 7 (Fisons) was added when the plants showed symptoms of $\mathrm{P}$ deficiency.

Success was judged by examination of roots for mycorrhiza formation and substrate for presence of spores. The soil sample was placed in a 
50-ml beaker containing tapwater and vigorously mixed. The heavier particles were allowed to settle for a few seconds before the supernatant was decanted on to a $30 \mu \mathrm{m}$ sieve, sluiced with tapwater to remove fine particles, and washed into a small dish for examination under a dissecting microscope. The mycorrhizas were stained by the following simple method, useful for roots with little pigmentation. Roots captured on the sieve, or retrieved during spore extraction, were placed in $20 \%(\mathrm{v} / \mathrm{v}) \mathrm{KOH}$ solution and held at room temperature for 1-3 days. The $\mathrm{KOH}$ was then decanted and the roots were rinsed briefly with tapwater. They were then put in acidified glycerol containing trypan blue (KoskE and GemmA 1989) at room temperature for at least a day or until they were assessed under a compound microscope for presence or absence of mycorrhizas. The samples were considered to be mycorrhizal if hyphal coils, intra-radical mycelium, vesicles, or arbuscules were present within the root cortical cells.

\section{Fungal strain testing}

Micropropagated 'Senga Sengana' plantlets were inoculated with 16 Finnish Glomus ramets. The inoculum consisted of pot culture substrate containing colonised strawberry roots, spores, and hyphae. The plants were kept in a growth chamber at $17 / 15^{\circ} \mathrm{C}$ (day/night), $50-60 \%$ relative humidity, under warm white (approx. $119 \mu \mathrm{mol} \mathrm{m}^{-2}$ $\mathrm{s}^{-1}$ ) artificial light (Oy Airam Ab, Finland) and a daylength of 16 hours. After transplanting, the bags were opened and the substrate was watered every 6-8 weeks to return them to their original weights. There was no additional fertilizer application during 13 months of cultivation.

Evaluation was carried out 13 months after inoculation when root colonization $(0-100 \%)$ and sporulation rate $(0-5)$ were assessed. The sporulation rating was based on a coarse scoring of 0 (none), 1 (very little - some spores but difficult to find), 2 (little - few spores, but found easily), 3 (moderate - spores easy to find), 4 (moderately abundant - spores easy to find), 5 (abundant spores very easy to find).

\section{Results}

\section{Initial development}

The system was developed successfully (Fig 1a), allowing both existing pot cultures to be maintained with reduced effort, and new cultures to be established by single- or multi-spore inoculation, root-fragment inoculation, incorporation of existing pot culture substrate, and from trap cultures with soil or washed plants. Watering to a pre-determined weight proved to be the best way of maintaining adequate soil water potential, though the addition of measured quantities of water at appropriate intervals, calculated from test pots, would increase the intervals between weighings. Watering by opening the bags was the most rapid method, though this could allow air- or water-borne contaminants to enter the system. The latter could be avoided by use of sterile water, and the former minimised by working under a laminar flow cabinet. However, for large numbers of cultures, this would prove tedious, and water can be injected through a self-sealing rubber patch attached to the bag. A further development consists of a tube fastened to the pot so that it reaches the bottom. Water and dissolved nutrients can then be introduced without opening the bags, either from a permanently positioned filter funnel (Fig 1b) or through a cotton plug.

In Scotland, Plantago lanceolata proved to be the easiest plant to work with, requiring little or no addition of fertilizer. Its characteristic of growing well under low light conditions makes it ideal for use in growth rooms, or in greenhouses in the north in winter. It also had the advantage of a relatively low growth habit, and is a good host for many different arbuscular mycorrhizal fungi. Its seed is readily available in many temperate countries during the late summer, and an hour's collecting will provide sufficient for several year's work. Other plants that grew well were Fragaria vesca and Plectranthus australis which have the advantage of being readily propagated from runners or cuttings. Although soils and substrates containing soils proved successful, the sand mixture facilitates the work of extracting spores for taxonomic study, and is now the preferred sub- 


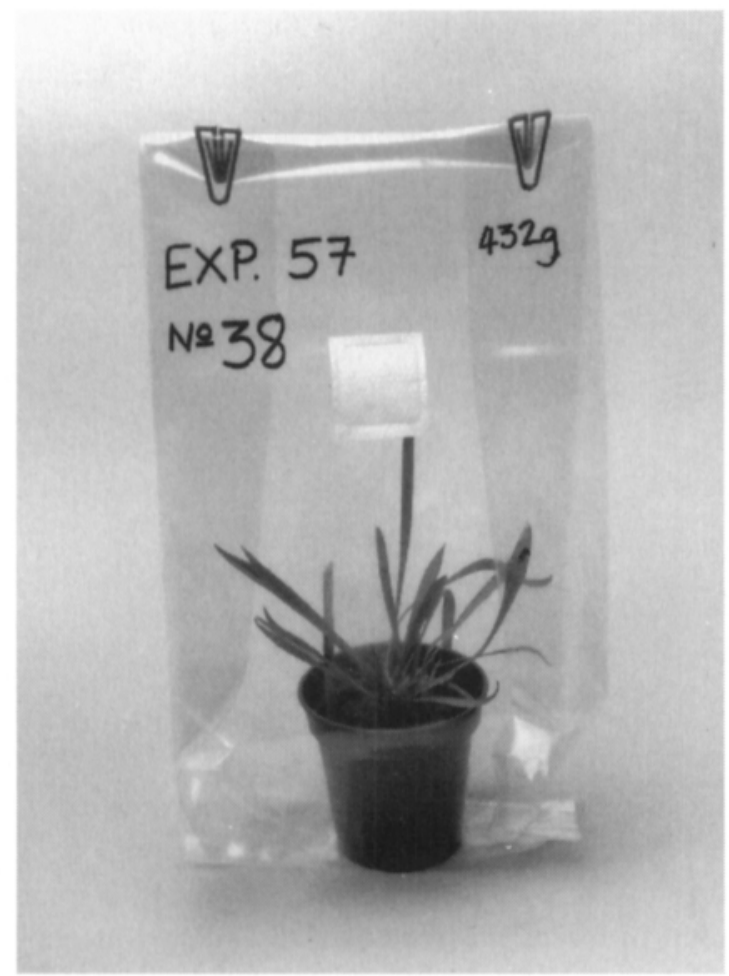

Fig. 1a. Sunbag with Plantago lanceolata showing method of sealing by double-folding top and securing with plastic paper clips. (Photo: Forestry Commission, UK)

strate at the Northern Research Station. The initial development work in Finland resulted in standardisation on a peat, sand and vermiculite mixture, which results in better plant growth, but which makes it somewhat more difficult to extract spores.

\section{Single-spore culture establishment}

The results differed, depending on the fungal species and substrate (Table 1). The Glomus species produced only two successful cultures in each substrate type, though this is an improvement over past repeated attempts at obtaining single-spore cultures of this fungus in open pot culture which had all failed. The Gigaspora rosea culture also produced equal numbers of successes, regardless of substrate, and for this species, there was only

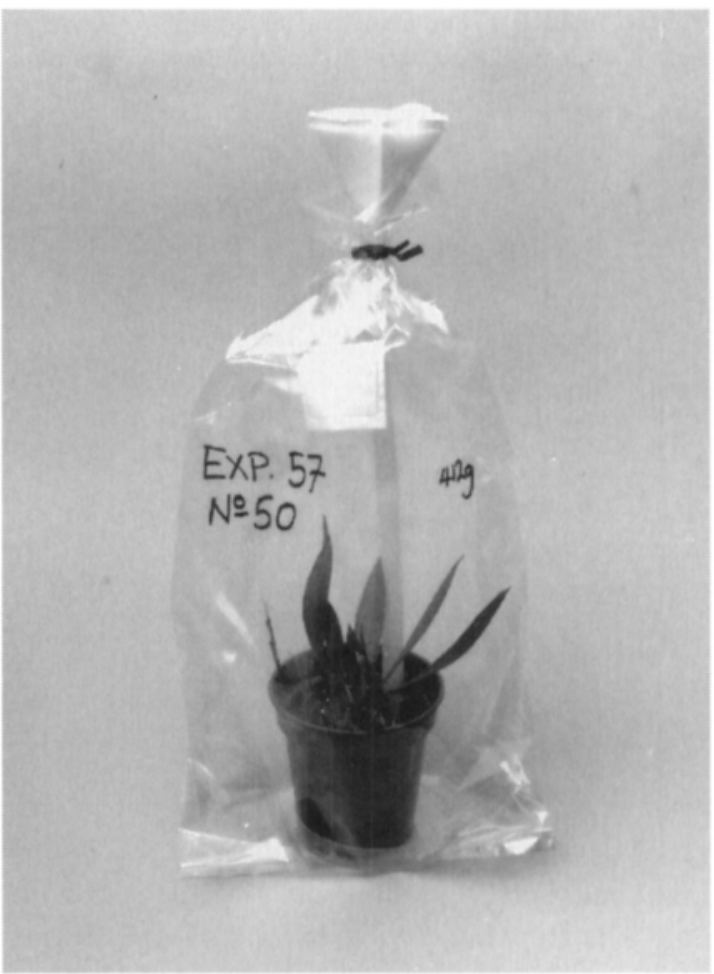

Fig. 1b. Sunbag with Plantago lanceolata showing the use of a funnel and filter paper to increase ease of watering. (Photo: Forestry Commission, UK)

one failure in each. Acaulospora longula produced different results, depending on substrate. There was no success in the sand, whereas eight of the ten attempts yielded successful cultures in the substrate containing Calval compost. None of the uninoculated controls became colonized.

\section{Fungal strain testing}

The Sunbag also proved to be a good cultivation enclosure for micropropagated strawberry plantlets resulting in $100 \%$ plant establishment, with the plants maintaining a dark green appearance throughout the 13 month long experiment. Initial growth was slow because the substrate was too dry in the beginning. After adjusting the moisture levels, the plantlets started to grow. During 13 months of cultivation, only one isolate was 
Table 1. Sporulation and mycorrhiza formation in single-spore isolation attempts in Sunbags, with Plantago lanceolata in two different substrates.

\begin{tabular}{llcccc}
\hline Species & Substrate & $\begin{array}{c}\text { Number of } \\
\text { isolation } \\
\text { attempts }\end{array}$ & $\begin{array}{c}\text { Pots with } \\
\text { spores on } \\
\text { first } \\
\text { sample }\end{array}$ & $\begin{array}{c}\text { Pots with } \\
\text { spores on } \\
\text { second } \\
\text { sample }\end{array}$ & $\begin{array}{c}\text { Pots with } \\
\text { mycorrhizas }\end{array}$ \\
\hline Glomus & Sand only & 10 & 2 & 2 & 3 \\
Glomus & Sand + Calval & 10 & 2 & 2 & 2 \\
Acaulospora longula & Sand only & 10 & 0 & 0 & 2 \\
Acaulospora longula & Sand + Calval & 10 & 6 & 8 & 7 \\
Gigaspora rosea & Sand only & 10 & 7 & 9 & 9 \\
Gigaspora rosea & Sand + Calval & 10 & 9 & 9 & 9 \\
Control & Sand only & 10 & 0 & 0 & 0 \\
Control & Sand + Calval & 10 & 0 & 0 & 0 \\
\hline
\end{tabular}

lost and this was due to a too long watering interval. After 13 months, the plants were still rather small and there was still space to grow inside the Bag. The strawberry roots grew slowly and were still very small after 13 months. Although no quantitative comparisons have been made, general observations revealed they were much smaller in the Sunbag than in open pots after the same length of time. It should be noted that the light levels used are low, and that plant growth, and perhaps mycorrhizal establishment, would be greater if much higher light levels, in the order of $420-740 \mu \mathrm{mol} \mathrm{m}^{-2} \mathrm{~s}^{-1}$ were used.

Sporulation was less abundant in the Sunbag system than in open pots of white clover. Out of 6 Glomus species, only Glomus hoi showed both abundant sporulation and high root colonization. Glomus caledonium (only one isolate tested) however, sporulated as well in the Sunbags as in the open pots. Sporulation of the remaining isolates, G. fistulosum, G. mosseae, G. clarum and G. claroideum, was poor, varying from none (0) to little (2). However, sporulation was not necessarily a good indication of colonization. For example with culture V14b spores were not produced, but the roots were completely colonized. Only one isolate out of 16, G. mosseae V143, failed completely to produce either mycorrhizas or spores (Table 2).

\section{Discussion}

Aggressive ramets such as those of Glomus hoi used in these trials not only established mycorrhizas within Sunbags, but sporulated abundantly

Table 2. Sporulation frequency (0-5) and root colonization $(0-100 \%)$ of 16 Glomus isolates in the Sunbag culture with strawberry 'Senga Sengana' in comparison with sporulation of the same isolates cultured in open pots with white clover 'Huia'.

\begin{tabular}{|c|c|c|c|}
\hline Isolate & $\begin{array}{c}\text { Sun bag } \\
\text { sporula- } \\
\text { tion }\end{array}$ & $\begin{array}{l}\text { Coloniza- } \\
\text { tion }\end{array}$ & $\begin{array}{c}\text { Open pot } \\
\text { sporula- } \\
\text { tion }\end{array}$ \\
\hline G. caledonium V126b & 3 & 90 & 3 \\
\hline G. clarum V161 & 0 & 10 & 4 \\
\hline G. clarum V157 & 1 & 70 & 3 \\
\hline G. claroideum V43a & 2 & 90 & 3 \\
\hline G. fistulosum V14b & 0 & 100 & 2 \\
\hline G. fistulosum V35 & 1 & 30 & 3 \\
\hline G. fistulosum V128 & 1 & 80 & 2 \\
\hline G. fistulosum V170 & 0 & 15 & 4 \\
\hline G. hoi V8 & 5 & 100 & 5 \\
\hline G. hoi V95a & 5 & 100 & 3 \\
\hline G. hoi V98 & 2 & 20 & 5 \\
\hline G. hoi V156 & 5 & 70 & 5 \\
\hline G. mosseae V57 & 1 & 50 & 2 \\
\hline G. mosseae V81b & 1 & 20 & 5 \\
\hline G. mosseae V143 & 0 & 0 & 3 \\
\hline G. mosseae V150 & 1 & 50 & 5 \\
\hline
\end{tabular}


(Table 2). Other species and strains did not develop so well in the particular conditions used, and there was an indication that factors involving the substrate influenced their success. For example, the Acaulospora delicata failed to establish from single spore cultures in the pure sand substrate, but was successful in most of the attempts in the soil-based substrate (Table 1). Some fungi, particularly those from tropical latosols, prefer low $\mathrm{pH}$ conditions (J Dodd, University of Kent, personal communication), while others may require alkaline conditions, and MOSSE and HEPPER (1975) indicated that $\mathrm{pH}$ is an important factor in establishment of arbuscular mycorrhizas. Further modifications of the system will be necessary to establish optimum conditions for particular species, but it is likely that, given the correct plantfungus combination and appropriate substrate, nutrient regime, moisture, light, and temperature conditions to optimise the growth of these symbionts, the system could be adapted to provide controlled maintenance and production of any arbuscular mycorrhizal fungus.

Critical study of arbuscular mycorrhizal fungi requires their production under controlled microbiological conditions Mosse (1962) and the production of single spore cultures of arbuscular mycorrhizal fungi is the best option to investigate the extent of their genetic variability and diversity (FANG et al. 1983). However, the integrity of such ramets (WALKER 1993) cannot be guaranteed in open pot cultures. The Sunbag system described here allows the long-term growth and purity of pot cultures derived from single spores to be maintained. The system can be used with many different substrates such as soil, sand, expanded clays, or even agars and polymeric water absorbing crystals (VESTBERG and UOSUKAINEN 1992). It can also be used to contain trap cultures, either from soil or from plants, or multispore cultures, and might be useful in studies of interactions with other fungi, bacteria, or soil dwelling organisms such as nematodes or arthropods. With appropriate autoclavable containers and aseptic methods, it can be used as a completely dixenic system, or at the other extreme, it can be used as a microcosm to contain more than one organism, whilst, depending on handling methods, reducing or eliminating external contamination. The bags are inexpensive, yet can still be washed and re-used several times to further reduce costs. The potential of the system for maintaining contamination-free pot cultures has been demonstrated, and it is now used routinely in both our laboratories.

Acknowledgements. We wish to thank Alice Broome, David Clark, and Keith Clifford, Forestry Authority, Scotland, for their technical assistance with the single-spore experiments, Glen Brearley, Forestry Authority, Scotland for photography, and Dr V Gianinazzi-Pearson, INRA, Dijon, France for supplying the culture of Gigaspora rosea. We also wish to thank Pirkko Jalkanen and Leena Eerola, Laukaa Research and Elite Plant Unit, for their technical assistance.

\section{References}

Allen, M. F., \& St. John, T. V. 1982. Dual culture of endomycorrhizae. In: Schenck, N.C. (ed.). Methods and Principles of Mycorrhizal Research. American Phytopathological Society, St. Paul, Minnesota. p. 85-89.

-, Moore, T. S., Jr, Christensen, M. \& Stanton, N. 1979. Growth of vesicular-arbuscular-mycorrhizal and nonmycorrhizal Bouteloua gracilis in a defined medium. Mycologia 71: 666-669.

BoudARGA, K., \& DeXheimer, J. 1990. Une méthode simple pour maintenir et multiplier les champignons des mycorhizes à vésicules et arbuscules. Agronomie 10: $417-422$
Fang, Y. C., McGraw, A. C., Modjo, H. \& HendriX, J. W. 1983. A procedure for isolation of single spore cultures of certain endomycorrhizal fungi. New Phytologist 97: 107-114.

Gilmore, A. E. 1968. Phycomycetous mycorrhizal organisms collected by open-pot culture methods. Hilgardia 39: 87-105.

Koske, R. E. \& Gemma, J. N. 1989. A modified procedure for staining roots to detect VA mycorrhizas. Mycological Research 92: 486-488.

MacDonald, R. M. 1981. A procedure for isolation of single-spore cultures of certain endomycorrhizal fun- 
gi. New Phytologist 93: 107-114.

Melhuish, JR., J. H., Wong, B. L. \& McQuattie, C. J. 1990. A culture unit system for the study of responses of mycorrhizal and non-mycorrhizal seedlings to treatments. Plant and Soil 129: 157-163.

MilnER, P. D. \& KITT, D. G. 1992. The Beltsville method for soilless production of vesicular-arbuscular mycorrhizal fungi. Mycorrhiza 2: 9-15.

Mosse, B. 1962. The establishment of vesicular-arbuscular mycorrhiza under aseptic conditions. Journal of General Microbiology 27: 509-520.
- \& HePper, C. M. 1975. Vesicular arbuscular mycorrhizal infections in root organ culture. Physiological Plant Pathology 5: 215-223.

Vestberg, M. \& Uosukainen, M. 1992. A new method for producing VA-mycorrhiza inoculum in a soil-free substrate. The Mycologist 6: 38 .

WALKER, C. 1993. Systematics and taxonomy of the arbuscular endomycorrhizal fungi (Glomales) - a possible way forward. Agronomie 12: 887-897.

Manuscript received February 1994

\title{
SELOSTUS
}

\section{Yksinkertainen ja taloudellisesti edullinen arbuskelimykorritsasienten suljettu tuotanto- ja ylläpitomenetelmä}

\author{
Christopher Walker ja Mauritz Vestberg
}

Forestry Authority, Iso-Britannia ja Maatalouden tutkimuskeskus

\begin{abstract}
Skotlannissa sijaitsevan tutkimuslaitoksen (Forestry Authority, Edinburgh) ja Maatalouden tutkimuskeskuksen välisenä yhteistyönä kehitettiin yksinkertainen ja edullinen arbuskelimykorritsasienten (AMS) viljely- ja ylläpitomenetelmä. Menetelmää testattiin pääasiassa kahdella testikasvilla, Plantago lanceolata L. ja Fragaria x ananassa Duch. Kasvien juuristoon siirrostettiin erityyppisiä AMsieniä, jonka jälkeen kasvit ruukkuineen suljettiin läpinäkyviin Sunbag® muovipusseihin, joissa oli $0.02 \mu \mathrm{m}$ mikrofiltteri ilmanvaihtoa varten. Sunbag-muovipussien sisällä
\end{abstract}

viljeltiin onnistuneesti erityyppisiä $\mathrm{AM}$-sieniä useilla erilaisilla kasvualustoilla.

Edullisuutensa ja helppokäyttöisyytensä takia Sunbagpussit täyttivät tutkimuksen asettamat tavoitteet. Menetelmää voidaan käyttää $\mathrm{AM}$-sienten pyydyskasviviljelmissä tai aloitettaessa AM-sienten puhdasviljelyjä kasvatus- tai kasvihuoneessa. Sunbag-pussien sisällä mykorritsaviljelmät eivät altistu ulkopuolisille kontaminaatioille ja systeemin hoito- ja kastelutarve on huomattavasti pienempi kuin avoimien ruukkujen vastaava tarve. 